\title{
Harnessing the Economic Potentials of Citrus Peel for Wealth Creation in Nigeria
}

\author{
Ifeyinwa C. Olife ${ }^{1^{*}} \quad$ Abubakar H. Mohammed ${ }^{2}$ \\ 1.Agriculture and Agro-Allied Department, Raw Materials Research and Development Council, Abuja, Nigeria \\ 2.Finance and Accounts Department, Raw Materials Research and Development Council, Abuja, Nigeria
}

\begin{abstract}
Citrus processing generates high volumes of co-products namely, peel and pulp and the peel comprises approximately $25 \%$ of total weight of the fruit. Because citrus peel is rich in nutrients such as carbohydrates, fats, cellulose and vitamins, its reprocessing is becoming increasingly important. Products derivable from citrus peel include dried peel, peel powder, pectin, peel essential oil, citric and lactic acids, brandy spirit, feed yeast, vinegar, marmalade and candied peel. Growing consumer interest towards citrus oil and powder has fuelled the demand for citrus peels market. Food and Beverages, Pharmaceuticals and Cosmetics industries in Nigeria depend on imports to meet the essential oils, resinoids and other citrus extracts requirement. According to the Nigeria Customs Service, a total of $183,607 \mathrm{~kg}$ of essential oils of citrus worth 244.84 million was imported into Nigeria form 2016 to 2020. Nigeria produces about 4.1 million tonnes of citrus fruits annually thereby generating over 1 million tonnes of citrus peels. The growing demand for natural flavouring agents and functional food products are driving the growth in the global citrus peel extract market for industrial applications. Therefore, there is need to develop citrus peel value chain in Nigeria for job and wealth creation. Aggregation of small groups of women and youths in cooperative societies together with training on best practices for peel collection and drying method to get premium peel is recommended to strengthen the supply chain. Establishment of citrus peel processing outfits is also recommended as a viable option to add more value to the commodity, produce raw materials for the industry and curb importation.
\end{abstract}

Keywords: Citrus peel, Citrus extract, essential oil, resinoids, value-chain, supply-chain

DOI: $10.7176 / \mathrm{JBAH} / 11-20-02$

Publication date:October $31^{\text {st }} 2021$

\section{Introduction}

Citrus fruits (Rutaceae family), including orange (Citrus sinensis), lemon (Citrus limon), mandarin (Citrus reticulata), and grapefruit (Citrus paradise), are the most produced fruits worldwide. Citrus fruits are highly consumed worldwide as fresh produce and juice but a significant portion of the fruit, about $40-60 \%$ is non-edible and discarded as waste (Manthey and Grohmann, 2001).

The production of citrus for fresh consumption far exceeds the demand; therefore, a great volume of the production is destined for the food industry, mainly for juice production. Although several commercial products including jams, jellies, flavoring agents for beverages and canned products are produced from citrus, it has been estimated that $40 \%$ of global citrus harvest is used in the production of juices (Berk, 2016).

Citrus processing generates high volumes of co-products namely, peel and pulp (seeds and membrane residues) (Mahato, et al., 2021; Sharma, et al., 2017). These co-products are a great source of several bioactive compounds including dietary fiber, minerals, organic acids, vitamins, phenolic acids, flavonoids, terpenes and carotenoids (Mahato, et al., 2018; Gomez-Mejia, et al., 2019). During citrus processing, a large amount of citrus peel is produced, which comprises approximately $25 \%$ of the total weight of the fruit (Yang, 2016a) and most often, the peel is discarded as waste despite the fact that it contains a wide variety of secondary components with substantial antioxidant activity in comparison to other parts of the fruit. The peel contains several functional components, such as essential oil, pectin, carotenoids, hesperidin, and limonene, which are important raw materials in the chemical and pharmaceutical industries. The utilization of these functional components of citrus peel has become an important part of the citrus-processing industry (Yang, 2016a). Because citrus peel is rich in nutrients such as carbohydrates, fats, food cellulose and vitamins, reprocessing of citrus peel is becoming increasingly important. Products derivable from orange peel include dried peel, peel powder, pectin, peel essential oil, citric and lactic acids, brandy spirit, feed yeast, vinegar, marmalade and candied peel.

\section{Global Citrus Production}

Citrus production takes place throughout the tropical and sub-tropical countries of the world and the production can be divided among four primary groups namely; sweet oranges, mandarins (also known as tangerines), grapefruit and lemons and limes. Citrus fruit is the highest value fruit crop in terms of international trade. Fresh fruit and processed citrus fruit markets are the two main citrus fruit markets in global trade. China is the leading citrus producer in the world with increased production of $3.8 \%$ year on year since 2014 (FAOSTAT, 2020).

Global annual citrus production was approximately 143.48 million tonnes in 2019 , out of which China 
produced 42.78 million tonnes, Brazil 19.31 million tonnes, India, 12.76 million tonnes, Mexico, 8.55 million tonnes, Spain, 6.80 million tonnes and the United States 6.66 million tonnes (Table 1). Among the citrus fruits, orange production constitutes around $54.84 \%$ of the total world production followed by mandarin with $24.70 \%$, lemon $20.44 \%$, lime $13.97 \%$ and grapefruit $6.47 \%$ (FAOSTAT, 2020).

Table 1. The world's top citrus producing countries in 2019

\begin{tabular}{|c|c|c|}
\hline Rank & Country & Total Citrus Production (Tonnes) \\
\hline 1 & China & $42,776,572.88$ \\
\hline 2 & Brazil & $19,305,081.80$ \\
\hline 3 & India & $12,763,518.65$ \\
\hline 4 & Mexico & $8,550,007.00$ \\
\hline 5 & Spain & $6,802,878.00$ \\
\hline 6 & USA & $6,662,954.61$ \\
\hline 7 & Turkey & $5,005,524.00$ \\
\hline 8 & Egypt & $4,766,378.00$ \\
\hline 9 & Nigeria & $4,114,676.00$ \\
\hline 10 & Argentina & $3,526,249.00$ \\
\hline
\end{tabular}

Source: FAOSTAT, 2020

Nigeria Citrus Production increased $1.7 \%$ year on year since 2014 . Yield was up $1.1 \%$ year on year while yield was put at 49,974 hectograms/hectare and citrus harvested area was up $0.7 \%$ year on year at 824,244 hectares in 2019. With 4,114,676 tonnes in 2019, Nigeria was ranked number 9 among other countries in Citrus Production. However, Nigeria was overtaken by Egypt in Africa, which was ranked number 8 in the world at 4,766,378 tonnes (FAOSTAT, 2020). Citrus fruit production in Nigeria from 2010-2019 is shown in Table 2.

Table 2: Citrus fruit production in Nigeria 2010 - 2019

\begin{tabular}{|l|l|}
\hline Year & Total Citrus Production (Tonnes) \\
\hline 2019 & $4,114,676$ \\
\hline 2018 & $4,071,176$ \\
\hline 2017 & $4,026,939$ \\
\hline 2016 & $3,982,701$ \\
\hline 2015 & $3,968,987$ \\
\hline 2014 & $3,777,000$ \\
\hline 2013 & $3,800,000$ \\
\hline 2012 & $3,900,000$ \\
\hline 2011 & $3,800,000$ \\
\hline 2010 & $3,800,000$ \\
\hline
\end{tabular}

Source: FAOSTAT, 2020

\section{Global Citrus Peel Extract Market}

Growing consumer interest towards citrus oil and powder has fuelled the demand for citrus peel market over the years. Citrus peels (Figure 1) are processed to essential oils and blended powder to infuse the aromatic flavors of lemon, lime, orange, tangerine and others in various products. The peel is rich in essential oils such as limonene (91-95\%), the major component of the essential oils. Other components include pinolene (1.83-2.61\%), n-octanol (1.50-1.64\%), myrcene (1.3\%), $\alpha$-pinene $(0.28-0.5 \%)$, linalool $(0.39 \%), \beta$-pinene $(0.38-1.05 \%), \gamma$-terpinene (0.41-1.09\%), camphene (0.27-0.35\%), decanal (0.11-0.35\%), etc. (Mahato, 2019).

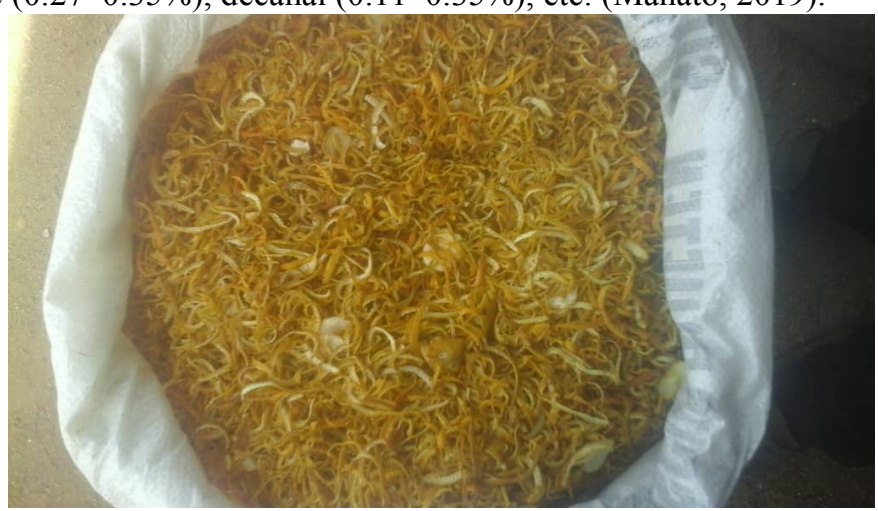

Figure 1. Dried citrus peel

The peel contains an abundance of fragrant substances that are extensively applied for processing into essential oils that are used commercially for flavoring foods, beverages, perfumes and cosmetics, among others 
and it can also be used as a raw material to develop complex sauces, candy and feed additives. The world's largest producers of citrus peel are Argentina and Mexico with USA, Spain, Peru and Bolivia as other prominent producers (Pagliaro, et al., 2016).

Citrus peel market is segmented into nature, fruit type, form and end use (Table 3). The amount of processed and exported dried citrus peel in major producing countries like China and Japan has increased tremendously (Yang, 2016b). The citrus peel extract market by region is segmented into North America, Europe, Asia-Pacific, Middle East \& Africa and South America (The Insight Partners, 2021).

In 2019, Peel of citrus fruit or melons was the world's $4009^{\text {th }}$ most traded product, with a total trade of $\$ 115 \mathrm{M}$. Between 2018 and 2019, the exports of Peel of citrus fruit or melons grew by $3.51 \%$, from $\$ 111 \mathrm{M}$ to $\$ 115 \mathrm{M}$. Trade in Peel of citrus fruit or melons represent $0.00063 \%$ of total world trade. The top exporters were Myanmar $(\$ 26.9 \mathrm{M})$, Spain $(\$ 21.3 \mathrm{M})$, Mexico $(\$ 7.59 \mathrm{M})$, Peru $(\$ 7.43 \mathrm{M})$ and China $(\$ 6.44 \mathrm{M})$ whereas top importers were China $(\$ 27.9 \mathrm{M})$, Germany $(\$ 18.8 \mathrm{M})$, France $(\$ 10.9 \mathrm{M})$, Japan $(\$ 8.95 \mathrm{M})$ and USA $(\$ 7.17 \mathrm{M})$. The fastest growing importers between 2018 and 2019 were China, Spain, Norway, Poland and Nigeria (Data from OEC Economic Complexity Indicators).

According to Zion Market Research Report (2019), the global orange extract market accounted for USD 540 million in 2018 and is expected to reach around USD 824 million by 2026 at a CAGR of $5.4 \%$ between 2019 and 2026 .

Table 3: Global citrus peels market segmentation

\begin{tabular}{|l|l|l|l|}
\hline Nature & Fruit type & Form & End use \\
\hline Organic & Lime & Powder & $\begin{array}{l}\text { Food processing (Bakeries, Snacks \& Savories, } \\
\text { Others \{processed meat, ice creams\}, etc.) }\end{array}$ \\
\hline Conventional & Lemon & Oil & $\begin{array}{l}\text { Beverage processing (Alcoholic beverages \& } \\
\text { Non-alcoholic beverages) }\end{array}$ \\
\hline & Orange & & Food services \\
\hline & Grapefruit & & Fertilizers \\
\hline & Others(Tangerine \& Pomelo) & & Animal feed \\
\hline & & & Home care \\
\hline & & & Cosmetics \& Personal care \\
\hline & & & Others (Herbal medicine, pharmaceuticals, etc. \\
\hline
\end{tabular}

Transparency Market Research, 2018

The global citrus peel extract market will continue to surge due to growing consumer interest in citrus oil and powder. Rising consumer awareness on the negative impact of chemical ingredients on health is also driving the market for natural products.

\section{Citrus Peel Extract Import and Export Market in Nigeria}

Food and Beverages, Pharmaceuticals and Cosmetics industries in Nigeria depend on imports to meet their essential oils, resinoids and other citrus extracts requirement. These commodities are required in small quantities but at high cost. According to the Nigeria Customs Service, a total of 183,607 kg of essential oils of citrus worth ₹244,840,593.00 was imported into Nigeria from 2016 to 2020 (Table 4).

Table 4: Essential oils of citrus imports to Nigeria, 2016 - 2020

\begin{tabular}{|c|c|c|c|c|c|c|c|c|c|c|c|c|}
\hline \multirow[t]{2}{*}{ Description } & \multicolumn{2}{|l|}{2016} & \multicolumn{2}{|l|}{2017} & \multicolumn{2}{|l|}{2018} & \multicolumn{2}{|l|}{2019} & \multicolumn{2}{|l|}{2020} & \multicolumn{2}{|c|}{ Total $(2016-2020)$} \\
\hline & $\begin{array}{l}\text { Qty } \\
\text { (kg) }\end{array}$ & Value ( & $\begin{array}{l}\text { Qty } \\
\text { (kg) }\end{array}$ & Value ( & $\begin{array}{l}\text { Qty } \\
\text { (kg) }\end{array}$ & Value (\$) & $\begin{array}{l}\text { Qty } \\
\text { (kg) }\end{array}$ & Value ( & $\begin{array}{l}\text { Qty } \\
\text { (kg) }\end{array}$ & Value ( $($ ) & $\begin{array}{l}\text { Qty } \\
\text { (kg) }\end{array}$ & Value (*) \\
\hline $\begin{array}{lll}\begin{array}{l}\text { Essential } \\
\text { orange }\end{array} & \text { oils } & \text { from } \\
\end{array}$ & 4,286 & $9,110,919$ & 2,315 & $1,789,468$ & 2,324 & $1,977,932$ & 495 & $1,127,667$ & 9,419 & $14,005,977$ & 18,838 & $28,011,954$ \\
\hline $\begin{array}{l}\text { Essential oils } \text { from } \\
\text { lemon }\end{array}$ & 7,442 & $14,514,822$ & 34 & 140,078 & 799 & $1,234,903$ & 671 & $4,618,407$ & 8,946 & $20,508,209$ & 17,892 & $41,016,419$ \\
\hline $\begin{array}{l}\text { Essential oils of citrus } \\
\text { fruit other }\end{array}$ & 10,420 & $\begin{array}{l}, 892,038 \\
\end{array}$ & 10,435 & $3,194,202$ & 8,917 & $3,670,305$ & 671 & $4,618,407$ & 30,444 & $16,374,952$ & 60,887 & $32,749,904$ \\
\hline $\begin{array}{l}\text { Essential oils of citrus } \\
\text { fruit (inclu }\end{array}$ & $\mathrm{NA}$ & $\mathrm{NA}$ & 15,179 & $28,532,025$ & $\mathrm{NA}$ & $\mathrm{NA}$ & $\mathrm{NA}$ & NA & 15,179 & $28,532,025$ & 30,358 & $57,064,050$ \\
\hline Resinoids & 17,848 & $6,051,641$ & 4,787 & $11,316,474$ & 2,575 & $7,499,690$ & 2,607 & $8,131,327$ & 27,816 & $32,999,133$ & 55,632 & $65,998,266$ \\
\hline Grand Total & 39,996 & $34,569,420$ & 32,750 & $44,972,248$ & 14,614 & $14,382,820$ & 4,444 & $18,495,808$ & 91,804 & $112,420,297$ & 183,607 & $244,840,593$ \\
\hline
\end{tabular}

Source: Nigeria Customs Service, 2021

In 2020, a total of $30,444 \mathrm{~kg}$ of essential oils of citrus fruit and others worth $\$ 16,374,952$ was imported into the country while $27,816 \mathrm{~kg}$ of resinoids worth $\$ 32,999,133$ was imported in 2020 . Essential oils of citrus and mixtures of odoriferous form imports to Nigeria from 2016 to 2019 were put at $776,686 \mathrm{~kg}$ valued at 1,285,800,768 (Table 5). Under the same period, 348,920 kg of essential oils of lemon, resinoids, oranges fresh or dried and mixtures of odoriferous substances valued at $\$ 56,738,744$ were exported from the Country. Orange fresh or dried had the highest export volume of $148,007 \mathrm{~kg}$ in 2016 followed by $100,000 \mathrm{~kg}$ in 2017 valued at $\$ 7,805,448$ and $\$ 9,583,535$ respectively. No resinoids export was recorded for 2016, 2017 and 2019. However, a total volume of $25,113 \mathrm{~kg}$ valued at $\$ 20,950,723$ was exported in 2018 (Table 6). 
Table 5. Essential oils of citrus and mixtures of odoriferous form imports to Nigeria 2016 - 2019

\begin{tabular}{|c|c|c|c|c|c|c|c|c|c|c|}
\hline \multirow[t]{2}{*}{ Description } & \multicolumn{2}{|l|}{2016} & \multicolumn{2}{|l|}{2017} & \multicolumn{2}{|l|}{2018} & \multicolumn{2}{|l|}{2019} & \multicolumn{2}{|c|}{ Total (2016 - 2019) } \\
\hline & Qty (kg) & Value (\$) & Qty (kg) & Value (\$) & Qty (kg) & Value (\$) & Qty (kg) & Value (\$) & Qty (kg) & Value (\$) \\
\hline $\begin{array}{l}\text { Oranges fresh or } \\
\text { dried }\end{array}$ & 10,590 & $2,042,383$ & 9,104 & $2,708,634$ & 8,781 & $1,6622,641$ & 8,508 & $1,050,274$ & 36,948 & $7,423,933$ \\
\hline $\begin{array}{l}\text { Lemons } \\
\text { limes } \\
\text { limes } \\
\text { dried }\end{array}$ & 15,022 & $12,702,802$ & 8,957 & $6,231,259$ & 12,554 & $7,001,292$ & 13,117 & $5,011,153$ & 49,650 & $30,946,515$ \\
\hline $\begin{array}{l}\text { Elsewhere } \\
\text { specified }\end{array}$ & 7,868 & $16,231,396$ & 4,401 & $12,096,885$ & 2,737 & $4,336,284$ & 1,973 & $4,514,873$ & 16,978 & $37,179,438$ \\
\hline $\begin{array}{l}\text { Mixtures of } \\
\text { odoriferous } \\
\text { substances of a } \\
\text { kind }\end{array}$ & 34,626 , & $122,168,656$ & 31,533 & $106,697,798$ & 36,950 & $76,842,424$ & NA & NA & 103,108 & $305,708,878$ \\
\hline $\begin{array}{l}\text { Mixtures of } \\
\text { odoriferous } \\
\text { substances of a } \\
\text { kind used in the } \\
\text { food or drink } \\
\text { industries }\end{array}$ & $\mathrm{NA}$ & $\mathrm{NA}$ & $\mathrm{NA}$ & $\mathrm{NA}$ & 32,862 & $104,525,699$ & 91,011 & $110,968,553$ & 123,872 & $215,494,252$ \\
\hline $\begin{array}{l}\text { Mixtures of, or } \\
\text { with basis of, } \\
\text { odoriferous }\end{array}$ & 37,808 & $28,728,052$ & 29,537 & $99,805,227$ & 140,318 & $46,282,046$ & $\mathrm{NA}$ & $\mathrm{NA}$ & 207,664 & $\begin{array}{l}174,815,324 \\
\end{array}$ \\
\hline $\begin{array}{l}\text { Mixtures of } \\
\text { odoriferous of a } \\
\text { kind }\end{array}$ & 14,980 & $19,544,767$ & 9,529 & $15,837,497$ & 12,192 & $18,499,578$ & NA & $\mathrm{NA}$ & 36,701 & $53,881,842$ \\
\hline 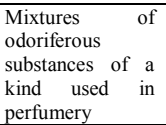 & NA & NA & NA & $\mathrm{NA}$ & 6,505 & $12,645,358$ & 15,654 & $15,741,099$ & 22,158 & $28,395,457$ \\
\hline $\begin{array}{l}\text { Mixtures of, or } \\
\text { with basis of, } \\
\text { odoriferous }\end{array}$ & 40,445 & $28,642,249$ & 16,191 & $71,491,715$ & 16,920 & $5,044,968$ & $\mathrm{NA}$ & $\mathrm{NA}$ & 73,556 & $105,178,932$ \\
\hline $\begin{array}{l}\text { Mixtures of } \\
\text { odoriferous of } \\
\text { substances of a } \\
\text { kind }\end{array}$ & 19,584 & $44,050,093$ & 10,554 & $38,945,828$ & 12,950 & $42,747,659$ & $\mathrm{NA}$ & $\mathrm{NA}$ & 43,089 & $125,743,581$ \\
\hline $\begin{array}{l}\text { Mixtures of } \\
\text { odoriferous of } \\
\text { substances of a } \\
\text { kind used in other } \\
\text { industries }\end{array}$ & NA & NA & NA & $\mathrm{NA}$ & 8,176 & $31,722,025$ & 9,389 & $45,024,044$ & 17,565 & $76,746,069$ \\
\hline $\begin{array}{l}\text { Mixtures of, or } \\
\text { with a basis of, } \\
\text { odoriferous }\end{array}$ & 14,161 & $41,027,445$ & 13,127 & $33,774,174$ & 18,072 & $49,484,930$ & $\mathrm{NA}$ & $\mathrm{NA}$ & 45,360 & $124,286,548$ \\
\hline Grand Total & 195,085 & $315,137,842$ & 132,932 & & 309,017 & $400,763,902$ & 139,651 & $182,310,005$ & 776,686 & $1,285,800,768$ \\
\hline
\end{tabular}

Source: Nigeria Customs Service, 2020

Table 6: Essential oils of lemon, resinoids, oranges fresh or dried \& mixtures of odoriferous substances export from Nigeria, $2016-2019$

\begin{tabular}{|c|c|c|c|c|c|c|c|c|c|c|}
\hline \multirow[t]{2}{*}{ Description } & \multicolumn{2}{|l|}{2016} & \multicolumn{2}{|l|}{2017} & \multicolumn{2}{|l|}{2018} & \multicolumn{2}{|l|}{2019} & \multicolumn{2}{|c|}{ Total (2016-2019) } \\
\hline & Qty (kg) & Value (N) & Qty (kg) & Value (\$) & Qty (kg) & Value ( $¥)$ & Qty (kg) & Value ( & Qty (kg) & Value ( \\
\hline $\begin{array}{l}\text { Essential Oils of } \\
\text { lemon }\end{array}$ & 12,342 & $4,663,623$ & $\mathrm{NA}$ & NA & NA & NA & NA & NA & 12,342 & $4,663,623$ \\
\hline Resinoids & NA & NA & NA & NA & 25,113 & $20,950,723$ & NA & NA & 25,113 & $20,950,723$ \\
\hline $\begin{array}{l}\text { Oranges fresh or } \\
\text { dried }\end{array}$ & 148,007 & $7,805,448$ & 100,000 & $9,583,535$ & 7,022 & $3,637,553$ & NA & NA & 255,030 & $21,026,536$ \\
\hline $\begin{array}{l}\text { Other citrus fruit, } \\
\text { fresh or dried }\end{array}$ & 3,771 & $3,976,938$ & 1,610 & $1,167,290$ & NA & NA & NA & NA & 5,381 & $5,144,228$ \\
\hline $\begin{array}{l}\text { Mixtures of } \\
\text { odoriferous } \\
\text { substances of a } \\
\text { kind }\end{array}$ & 14,362 & 305 & 6,761 & $1,977,455$ & 5,000 & 137,970 & NA & NA & 26,123 & $2,115,730$ \\
\hline $\begin{array}{l}\text { Mixtures of } \\
\text { odoriferous } \\
\text { substances of a } \\
\text { kind used in the } \\
\text { food or drink } \\
\text { industries }\end{array}$ & NA & NA & NA & NA & 14,522 & $1,090,429$ & 10,410 & $1,747,476$ & 24,931 & $2,837,904$ \\
\hline Grand Total & 178,482 & $16,446,314$ & 108,371 & $12,728,280$ & 51,657 & $25,816,675$ & 10,410 & $1,747,476$ & 348,920 & $56,738,744$ \\
\hline
\end{tabular}

Source: Nigeria Customs Service, 2020

\section{Citrus Peel Production and Handling in Nigeria}

Industrial extraction of orange juice produces large volumes of solid waste, mainly orange peel because the peel constitutes approximately $25 \%$ of the total weight of the fruit. These wastes are considered ecological problem because they are dumped on the land around the factories where they putrefy. Therefore, the management of orange peel waste constitutes economic and environmental problems in areas where there are citrus processing industries and at fruit markets. Traditional handling techniques such as composting and animal feeding are not economically attractive.

Nigeria produces about 4.1 million tonnes of citrus fruits annually thereby generating over 1 million tonnes of citrus peels by estimation. Of all the citrus fruits, sweet orange is the commonest, most widely cultivated and consumed in the country. Since the ban on consumer pack fruit juice in 2002 by the Federal Government of Nigeria, 
local processing of citrus in the country has been on the increase to meet increasing local demand for fruit juice. Consumption of fresh and processed citrus has been increasing by approximately $10 \%$ per annum and this increased processing is generating more citrus peel waste (Olife, et al, 2015).

Major citrus producing States in Nigeria include Benue, Nassarawa, Kogi, Ogun, Oyo, Osun, Ebonyi, Kaduna, Taraba, Ekiti, Imo, Anambra, Kwara, Edo and Delta (UNCTAD, 2007). Across the country, orange peels are discarded as waste after consumption of fresh fruits or juice production. Fresh fruit markets across the country are also replete with waste due to lack of functional disposal system in local markets.

Business opportunities in the value chain ranges from collection, drying, packaging for local and export market, processing to different secondary raw materials for supply to user industries. The collection stage involves very little capital and therefore ideal for people with low start-up capital. To kick-start the development of citrus peel value chain in Nigeria, the Raw Materials Research and Development Council (RMRDC) organized a stakeholders' meeting tagged "Promotion of Technologies for Harnessing Economic Potentials of Orange Peel and its Utilization as Industrial Raw Material" in 2019. The stakeholders' meeting created awareness on the waste to wealth potentials of the peels. However, more still need to be done if the country is to be a player in the global orange peel and extract market.

\subsection{Way Forward}

Nigeria is ranked $9^{\text {th }}$ in global citrus production but not listed among the world's largest producers of citrus peel and its extracts. The peel is mostly considered as waste in the country despite its industrial applications and economic value. Strategies to develop the value chain and harness the potentials are therefore recommended. These measures will not only earn foreign exchange for the country, but also conserve foreign exchange, create jobs and protect the environment.

\section{- Sensitization/awareness creation}

Sensitization programmes should be organized at the grassroots to educate people on the wate to wealth potentials of citrus peel.

\section{- $\quad$ Formation of collectors groups}

Women and youths should be organized in small groups of collectors within their local environments for the collection of peels from processing industries, restaurants, hotels, bars, fruit markets, households, etc.

\section{- $\quad$ Training of collectors}

Collectors should be trained on best practices in peel collection and drying to ensure premium quality.

\section{- Establishment of aggregation or buying centres}

The centres should serve as aggregation centre where buying agents can buy the dried peels from collectors.

\section{- $\quad$ Establishment of citrus peel processing outfits}

Production of value-added products from the peel is also recommended to reduce importation of these products to the country.

\section{- Development of market route for dried citrus peel and citrus peel powder}

Drying of citrus peels and conversion to powder are the initial steps in the value chain. These two products (dried peel and powder) are traded in the international market and developing the market route will also create wealth among the primary value chain actors.

\section{Conclusion}

Citrus peel is an inexpensive renewable resource for the production of secondary raw materials for industrial applications. Citrus waste from processing industries has been increasing due to increased demand for processed and packaged food and increased output has also been witnessed in restaurants, hotels, bars, fruit markets, etc. because of improved healthy lifestyle. The peel gains value through collection, drying, packaging and processing to different products ranging from powder to essential oil. With the growing demand for natural flavouring agents and functional food products, the global citrus peel extract market for industrial applications will continue to grow.

Treating citrus peel as waste meant for the waste bin in Nigeria is a huge economic waste given the arrays of secondary raw materials derivable from it. The peel is also an export commodity especially in dried and powdered forms. There is need, therefore, to develop citrus peel value chain in Nigeria for job and wealth creation.

\section{References}

Adelaja, B.A. \& Olaniyan,A.A. (2000): Production of the ten most important fruit trees in Nigeria In Agronomy in Nigeria. Edited by M.O Akoroda. pp 106-115

Berk, Z. (2016). By-products of the citrus processing industry. In Citrus Fruit Processing; Berk, Z., Ed.; Academic Press: London, UK, pp. 219-233.

FAO (2021). Top countries in citrus production 1961-2019.

FAOSTAT (2021). Statistics Division, Food and Agriculture Organization of the United Nations. Available online: http://www.fao.org/ faostat/en/. 
Gómez-Mejía, E.; Rosales-Conrado, N.; León-González, M.E. \& Madrid, Y. (2019). Citrus peels waste as a source of value-added compounds: Extraction and quantification of bioactive polyphenols. Food Chem. 295, 289299.

Mahato, N., Sharma, K., Sinha, M., Dhyani, A., Pathak, B., Jang, H., Park, S., Pashikanti, S. \& Cho, S. (2021). Biotransformation of Citrus Waste-I: Production of biofuel and valuable compounds by fermentation. Processe: 9, 220.

Mahato, N.; Sharma, K.; Koteswararao, R.; Sinha, M.; Baral, E. and Cho, M.H. (2019). Citrus essential oils: extraction, authentication and application in food preservation. Crit. Rev. Food Sci. Nutr. 59, 611-625.

Mahato, N., Sharma, K., Sinha, M. \& Cho, M.H. (2018). Citrus waste derived nutra-/pharmaceuticals for health benefits: Current trends and future perspectives. J. Funct. Food, 40, 307-316.

Manthey, J.A. \& Grohmann, K. (2001). Phenols in citrus peel byproducts. Concentrations of hydroxycinnamates and polymethoxylated flavones in citrus peel molasses. J. Agric. Food Chem., 49 (7), pp. 3268-3273

Nigeria Customs Service (2020). Nigeria Integrated Customs Information System

Nigeria Customs Service (2019). Nigeria Integrated Customs Information System $\mathrm{i}_{\mathrm{i}}$

OEC Economic Complexity Indicators: Peel of citrus fruit or melons

Olife, I.C., Ibeagha, O.A. \& Onwualu, A.P. (2015). Citrus fruits value chain development in Nigeria. Journal of Biology, Agriculture and Healthcare, Vol.5, No.4, pp.36-47.

Pagliaro, M., Ciriminna, R., Fidalgo, A., Delisi, R. \& Ilharco, L. (2016). Pectin production and global market. Agro Food Industry Hi Tech. 27.

Sharma, K, Mahato N, Cho M.H. \& Lee, Y.R. (2017). Converting citrus wastes into value-added products: Economic and environmently friendly approaches. Nutrition. 34:29-46.

The Insight Partners (2021). Market Research Report: Orange Peel Extract Market Forecast to 2028 - Covid-19 Impact and Global Analysis by Form, Nature, Application, Distribution Channel and Geography.

Transparency Market Research (2018). Citrus Peels Market - Global Industry Analysis, Size, Share, Growth, Trends, and Forecast 2019 - 2027

UNCTAD (2007). Market Information in the Commodities Area: Citrus Fruit

USDA (2021). Citrus: World Markets and Trade

Yang, S. (2016a). Chapter 1 - Functional Components of Citrus Peel. In: Comprehensive Utilization of Citrus ByProducts. Yang Shan (Eds.) pp.1-13. Academic Press, ISBN 9780128097854.

Yang, S. (2016 $_{\mathrm{b}}$. Chapter 6 - Drying of Citrus Peel and Processing of Foods and Feeds. In: Comprehensive Utilization of Citrus By-Products. Yang Shan (Eds). Pp75-83. Academic Press, ISBN 9780128097854.

Zion Market Research (2019). Orange Extract Market by Form, By Nature, By Application and By Distribution Channel: Global Industry Perspective, Comprehensive Analysis and Forecast, 2018-2026. 